NBER WORKING PAPER SERIES

\title{
ESTIMATING THE RETURNS TO URBAN BOARDING SCHOOLS: EVIDENCE FROM SEED
}

\author{
Vilsa E. Curto \\ Roland G. Fryer, Jr. \\ Working Paper 16746 \\ http://www.nber.org/papers/w16746 \\ NATIONAL BUREAU OF ECONOMIC RESEARCH \\ 1050 Massachusetts Avenue \\ Cambridge, MA 02138 \\ January 2011
}

We are grateful to Eric Adler, Anjali Bhatt, Pyper Davis and Rajiv Vinnakota for their cooperation in collecting data necessary for this project. Will Dobbie and Meghan Howard provided exceptional research assistance. Support from the Education Innovation Laboratory at Harvard University (EdLabs) is gratefully acknowledged. Correspondence can be addressed to either of the authors by email. The usual caveat applies. The views expressed herein are those of the authors and do not necessarily reflect the views of the National Bureau of Economic Research.

NBER working papers are circulated for discussion and comment purposes. They have not been peerreviewed or been subject to the review by the NBER Board of Directors that accompanies official NBER publications.

(C) 2011 by Vilsa E. Curto and Roland G. Fryer, Jr.. All rights reserved. Short sections of text, not to exceed two paragraphs, may be quoted without explicit permission provided that full credit, including (C) notice, is given to the source. 
Estimating the Returns to Urban Boarding Schools: Evidence from SEED

Vilsa E. Curto and Roland G. Fryer, Jr.

NBER Working Paper No. 16746

January 2011

JEL No. I20,J01,J15

\section{ABSTRACT}

The SEED schools, which combine a "No Excuses" charter model with a five-day-a-week boarding program, are America's only urban public boarding schools for the poor. We provide the first causal estimate of the impact of attending SEED schools on academic achievement, with the goal of understanding whether changing a student's environment through boarding is a cost-effective strategy to increase achievement among the poor. Using admission lotteries, we show that attending a SEED school increases achievement by 0.198 standard deviations in reading and 0.230 standard deviations in math, per year of attendance. Despite these relatively large impacts, the return on investment in SEED is less than five percent due to the substantial costs of boarding. Similar "No Excuses" charter schools - without a boarding option - have a return on investment of over eighteen percent.

Vilsa E. Curto

Harvard University

Cambridge, MA 02138

vilsa.curto@post.harvard.edu

Roland G. Fryer, Jr.

Department of Economics

Harvard University

Littauer Center 208

Cambridge, MA 02138

and NBER

rfryer@fas.harvard.edu 


\section{Introduction}

The racial achievement gap is an empirical fact that manifests itself in every American school district, at every level of schooling, and on nearly every academic assessment. The National Assessment of Educational Progress (NAEP), which measures students' levels of proficiency in reading and math, highlights this fact. ${ }^{1}$ Among fourth graders, 43.2 percent of white students and 12 percent of black students are proficient in reading. In math, 50.9 percent of white students and 14 percent of black students are proficient. Similarly, among eighth graders, 40.4 percent of white students and 10.6 percent of black students score proficient in reading. Math scores exhibit a similar pattern. There is not one urban school district in NAEP in which more than twenty-one percent of black students are proficient in reading or math (Fryer, forthcoming).

There have been many attempts to close the achievement gap, including early childhood interventions; smaller schools and classrooms; mandatory summer school; merit pay for principals, teachers, and students; ending social promotion; using "smart" technology; and policies to lower the barrier to teaching via alternative paths to accreditation (Currie and Thomas, 1995; Krueger and Whitmore, 2001; Puma et al., 2010; Bloom et al., 2010; Krueger, 1999; Jacob and Lefgren, 2004; Podgursky and Springer, 2007; Fryer, 2010a,b; Jacob and Lefgren, 2009; Decker et al., 2004; Kane et al., 2008). Yet, these policies have not substantially reduced the gap in even the most reform-minded districts. There is recent enthusiasm for charter schools - publicly funded schools that operate outside the direct control of local school districts - but the bulk of the evidence suggests that they perform roughly the same as traditional public schools (Zimmer et al., 2009; Gleason et al., 2010). ${ }^{2}$

The lack of progress in closing the racial achievement gap has caused many to question whether schools alone can increase achievement among the poor or whether the challenges children bring

\footnotetext{
${ }^{1}$ NAEP is a nationally representative set of assessments administered every two years to fourth, eighth, and twelfth graders that cover various subject areas, including mathematics and reading. Individual schools are first selected for participation in NAEP in order to ensure that the assessments are nationally representative, and then students are randomly selected from within those schools. Both schools and students have the option to not participate in the assessments. Tests are given in multiple subject areas in a given school in one sitting, with different students taking different assessments. Assessments are conducted between the last week of January and the first week of March every year. The same assessment is given to all students within a subject and a grade during a given administration.

${ }^{2}$ There are, however, several charter schools and charter management organizations that have demonstrated marked success (e.g., Knowledge is Power Program, Harlem Children's Zone, and Harlem Success Academies) (Hoxby and Murarka, 2009; Abdulkadiroglu et al., 2009; Angrist et al., 2010; Dobbie and Fryer, forthcoming; Gleason et al., 2010). Raymond (2009) estimates that 17 percent of charter schools outperform traditional public schools.
} 
to school as a result of being reared in dysfunctional families and failing communities are too much for all but the best educators to overcome. Consider the case of Washington, D.C.: 24.4 percent of blacks live in poverty, only 23 percent of black children are reared in a two-parent household, 7.4 percent of black women will give birth while they are still teenagers, and nearly 50 percent of black men between the ages of 18 and 35 are under Criminal Justice supervision (Lotke, 1998). ${ }^{3}$ School safety is also a major concern: in 2007, 11.3 percent of high school students reported being threatened or injured with a weapon on school property during the previous twelve months. ${ }^{4}$ Brooks-Gunn et al. (1999) argue that children who grow up in low-income families tend to score lower than children from more affluent families on assessments of health, cognitive development, school achievement, and emotional well-being. In this scenario, combating poverty, having more constructive out-of-school time, or minimizing negative social interactions with a student's environment will lead to better and more-focused instruction in school and increased student achievement.

One potential solution, which has yet to be tested, is coupling achievement-minded schools with a boarding program that ensures students have a positive and nurturing environment outside of school. ${ }^{5}$ Theoretically, taking students away from their home environment and placing them in a boarding program could have one of three effects. If the environment that the typical student encounters in a boarding school is, on net, more positive than her home environment and the

\footnotetext{
${ }^{3}$ Figures on poverty and family structure were obtained from the U.S. Census Bureau's 2006-2008 American Community Survey 3-Year Estimates. In Washington, D.C., 80 percent of white children are reared in a two-parent household. The percent of black women who will give birth as teenagers was estimated using data from the National Vital Statistics System. There were 908 births to black women aged 15-19 in Washington, D.C., in 2008. Based on data from the U.S. Census Bureau's 2006-2008 American Community Survey 3-Year Estimates, there are about 12,332 black women aged 15-19 in Washington, D.C. The corresponding birth rate among black women in Washington, D.C., aged 15-19 is about 7.4 percent. Being under Criminal Justice supervision is defined as being in prison or jail, being on probation or parole, being out on bond, or being sought on an arrest warrant.

${ }^{4}$ Figure obtained from the National Center for Education Statistics' 2008 report on Indicators of School Crime and Safety.

${ }^{5}$ At least one residential program targeted to disadvantaged youths - Job Corps - has had considerable success, leading to a 15 percent increase in annual earnings, reduced dependence on welfare and public assistance by about 2 weeks per year, and a fivefold increase in the probability of obtaining a high school diploma. Job Corps is a program providing economically disadvantaged youths between ages 16 and 21 with basic education, vocational training, and other services in a residential setting. Its primary purpose is to improve the long-term productivity and lifetime earnings prospects of high school dropouts (Mallar, 1982). However, JOBSTART - a program intended to provide training and support similar to that of Job Corps, but in a less expensive, non-residential setting - has had statistically insignificant results. Cave et al. (1993) found that effects on earnings four years after the program were not statistically significant, there was little impact on youths' receipt of public assistance, and that JOBSTART participants increased their educational attainment, but this was mostly through receipt of the GED (General Educational Development) rather than completion of high school. This evidence suggests that residential programs could be more effective at delivering education and support to disadvantaged youths in urban areas than non-residential programs.
} 
differences between them are correlated with academic achievement, then boarding schools will yield positive gains in test scores. If the boarding school environment is not more conducive to achievement, or if the new environment causes psychological or emotional distress or other behavioral responses that hinder a student's academic performance, then boarding schools may have a negative effect on achievement. Finally, if the positive and negative aspects of placing a student in a boarding program roughly balance out, or the differences in the home environment and the boarding school are not correlated with achievement (e.g., less television in boarding school), then the effects of boarding school will be negligible.

The SEED schools, located in Washington, D.C., and Baltimore, Maryland, are America's only urban public boarding schools for the poor. These schools combine a "No Excuses" charter school model with a five-day-a-week boarding program, which provides a rare laboratory to estimate the returns (both average and marginal) to attending an urban boarding school. The SEED schools serve students in grades six through twelve. Like other "No Excuses" charter schools (e.g., Knowledge is Power Program or Harlem Children's Zone), SEED schools have an extended school day, extensive after-school tutoring for students who need support, rely heavily on data to drive instruction, and have a paternalistic culture with high expectations. The middle school curriculum focuses on developing basic skills in reading and math, and the high school uses an intensive collegepreparatory curriculum that requires all students to take the SAT or ACT college admissions test and apply to at least five colleges or universities in order to graduate.

To account for the fact that students who attend SEED schools may not be a random sample, we exploit the fact that SEED is required to select students by random lottery when demand for the school exceeds the supply of admission slots available. The treatment group is composed of students who won the lottery and the control group is comprised of students who entered the lottery but did not win. This allows us to provide a set of causal estimates of the effect of being offered admission into SEED on student achievement. ${ }^{6}$

The results we obtain are interesting and, in some cases, quite surprising. Our lottery estimates reveal that SEED schools are effective at increasing the achievement of the poorest minority

\footnotetext{
${ }^{6}$ Our analysis focuses on the results from the SEED School of Washington, D.C., which has been in operation since 1998. The SEED School of Maryland has only been open since 2008. The first year of operation is usually the most difficult one for any school, and results tend to improve over time, so estimates of effect sizes from the first or second year of operation may not be representative of the effect sizes that one would expect from such a school once it was more established (Zimmer et al., 2009).
} 
children. Students who enroll gain 0.198 standard deviations in reading and 0.230 standard deviations in math, per year. Taken at face value, these effects are enough to close the black-white achievement gap in both subjects in four years. Girls who attend SEED score significantly higher than boys in both subjects, but due to large standard errors, we are only able to reject the null hypothesis of equality in reading. Free lunch students also outperform non-free lunch students in reading. Treatment effects for special education and non-special education students are statistically the same, though we are underpowered to detect small to modest differences.

The impact of SEED on student achievement is significantly larger than that of the average charter school. Compared to other "No Excuses" charter schools, SEED students' gains in math are similar but gains in reading are larger (Abdulkadiroglu et al., 2009; Angrist et al., 2010; Dobbie and Fryer, forthcoming). The costs, however, are also substantially larger. SEED spends approximately $\$ 39,000$ per student, per year. Following the approach in Krueger (2003), we estimate that the return on investment in SEED is 4.59 percent. For comparison, the return on investment in a typical "No Excuses" charter school - without a boarding option - is 18.50 percent. In other words, based on evidence from the SEED school, the marginal benefit of boarding students five days a week to provide them a nurturing environment away from potentially negative interactions is outweighed by the costs. ${ }^{7}$ A very important caveat is that, by necessity, our returns are based solely on achievement test scores and do not encompass other outcomes such as mental health, teen pregnancy, happiness and well-being, or educational attainment, which may be positively affected by a boarding program. A more complete cost-benefit analysis of SEED will be possible with the passage of time.

The next section of the paper presents a theoretical framework for analyzing the effect of urban boarding schools for the poor on student achievement. Section 3 discusses our data and research design. Section 4 presents the results of our analysis, and the last section concludes. There are three online appendices: Appendix A details programs and services provided by SEED schools in both their academic and residential boarding programs; Appendix B is a data appendix that details our sample and variable construction; and Appendix C provides details of our cost-benefit calculations.

\footnotetext{
${ }^{7}$ This is consistent with evidence from the Moving to Opportunity Experiment, which demonstrates that moving families to lower-poverty neighborhoods has virtually no impact on academic achievement. See Kling et al. (2007).
} 


\section{Boarding Schools and Student Achievement}

Below, we discuss the major hypothesis about how boarding schools may affect student achievement for low-income minority groups. ${ }^{8}$

\section{The Costs of Urban Boarding Schools}

A large literature in sociology and psychology describes the potential costs of boarding schools, though much of the evidence is qualitative and should be interpreted with care. In this section, we highlight four potential channels: homesickness, stress, lack of positive parental support or input, family detachment, and loss of identity (or what sociologists refer to as "double marginalization") (Fisher et al., 1984, 1985, 1986; Dick et al., 1993; Arieli et al., 2001; LaFromboise et al., 1998; Fordham and Ogbu, 1986; Fryer and Torelli, 2010; Datnow and Cooper, 1997). ${ }^{9}$ If young students living away from home are homesick and as a result have difficulty concentrating or coping with academic work, as Fisher et al. (1985) reported was the case in a sample of first-year university students, then this could have adverse effects on student achievement. In a study of Scottish boarding school students, Fisher et al. (1986) found that approximately 70 percent reported being homesick at some point during their first year. Relatedly, Dick et al. (1993) suggest that adolescents are exposed to particularly high levels of stress as a result of social, physical, cognitive, and academic growth, and these stress levels can be exacerbated by sending a youth to boarding school, particularly if the youth lacks familial support.

Lack of parental support and input is a third potential cost of boarding schools. If parental

\footnotetext{
${ }^{8}$ Boarding schools have a long and controversial history as educational and socializing institutions in a variety of socioeconomic contexts around the world (Kahane, 1988). For instance, elite English and American boarding schools have been described by sociologists as conservative institutions aimed at preserving an existing social order (Kahane, 1988; Levine, 1980; Cookson and Persell, 1985; Zweigenhaft, 1992). In stark contrast, boarding schools also have a history as tools for assimilation for groups such as Native Americans (Adams, 1995; Ellis, 1996). In the late 1800s and early 1900s, Congress aggressively pushed to assimilate Native Americans through education, establishing 147 reservation day schools, 81 reservation boarding schools, and 25 off-reservation boarding schools with the explicit goal of inculcating Native American children with Protestant values (Adams, 1988).

${ }^{9}$ Other potential channels through which boarding schools may impose costs on students include: lack of parental supervision leading to engagement in adult behaviors, failure to develop independent decision-making ability as a result of overdependence on boarding school structure, or increased likelihood of substance abuse. Although there is evidence that a lack of parental supervision may make students more likely to engage in substance abuse and sexual activity (Barnes and Farrell, 1992; Chilcoat and Anthony, 1996; Dishion and McMahon, 1998), the effect of attending boarding school on this channel is unknown. There is also a lack of evidence of the effects of boarding schools on developing independence, or what effect this would have on achievement. While there is a literature on boarding schools as a trigger for increased substance abuse (Koss et al., 2003; Kleinfeld and Bloom, 1977), this is generally focused on Native American boarding schools, which students often attended unwillingly; its applicability to urban public boarding schools is doubtful.
} 
interactions such as discussing school-related activities at home each evening or getting help with homework contribute to academic success, then boarding schools may undercut academic achievement. If the boarding program results in parental detachment and less parental input, then the SEED schools may be less accountable to parents and school quality may be less than one would expect given other observable school inputs.

A fourth potential cost of urban boarding schools is one that may be particularly acute in urban areas: loss of identity. Arieli et al. (2001) note that the risk of so-called "mainstreaming settings" residential settings intended to introduce children from weaker socioeconomic classes to the social and cultural mainstream of a society - is that they can confuse a child's sense of identity, a problem that sociologists have termed "double marginalization." In these circumstances, black students can develop an oppositional identity, view academic achievement as the prerogative of white people, and discourage their peers from striving for academic success, accusing them of "acting white" if they strive for success (Fordham and Ogbu, 1986).

Taking all the potential channels together, it is plausible that attending a boarding school could have significant costs.

\section{The Benefits of Urban Boarding Schools}

A complementary literature in sociology and psychology emphasizes the potential benefits of urban boarding schools including: placing students in safer and less volatile environments, minimizing negative parental and community interactions, and ensuring that students have positive adult role models, are provided with nutritious foods, spend less time being idle, and so on (Gonzales et al., 1996; Leventhal and Brooks-Gunn, 2000; Ainsworth, 2002; Datcher, 1982; Kemper, 1968; Wacquant and Wilson, 1989). As stated in the Introduction, minority children are significantly more likely to be reared in a single female-headed household; 69 percent of black family households with children under the age of 18 in Washington, D.C., are single-mother households; for whites, this figure is 14 percent. ${ }^{10}$ Many believe that until children's basic needs - security, stability, and frequent and positive parental interactions - are met, student achievement will not increase (Gonzales et al., 1996; Ainsworth, 2002; Rothstein, 2004; Duncan and Magnuson, 2005; Brooks-Gunn and Markman, 2005). In this scenario, putting students in more stable environments, changing the nature of their interactions with their home environment, providing nutritious foods,

\footnotetext{
${ }^{10}$ Data obtained from the U.S. Census Bureau's 2006-2008 American Community Survey 3-Year Estimates.
} 
decreasing idleness through after-school and evening programs, and providing positive and caring adults or role models may provide important structure that will lead to greater focus in schools and increased academic achievement.

Perhaps equally important, boarding schools can be leveraged as agents for delivering scholastic and social capital to their students. Many "No Excuses" charter schools desire to instill mainstream middle-class values into their students, as reformers posit that this type of education is essential for improving academic achievement among low-income students (Rosen, 1956; Mickelson, 1990; Whitman, 2008). Indeed, the slogan for the nation's largest network of charter schools is an explicit endorsement of the Protestant work ethic ("Work hard. Be nice."). In his analysis of six high-performing inner-city schools, Whitman (2008) argues that the success of schools such as KIPP Academy and Amistad Academy (and SEED, one of the six schools profiled in the book) can be attributed to the fact that these schools are paternalistic, attempt to "micro-manage" their students' lives, and teach students to act according to middle-class values. If this process of middleclass acculturation is a key ingredient to academic success, then a school equipped with a boarding program could be more effective at inculcating these values in its students.

\subsection{A Model}

We now demonstrate the costs and benefits of urban boarding schools in a stylized framework designed to formalize the discussion above; the empirical results to come do not depend on the specific assumptions of the model.

Let there be a continuum of agents with unit mass. Student achievement, denoted $\theta$, is generated by a smooth, continuous, and twice differentiable production function, $f\left(e, p, s, x_{1}, \ldots, x_{n}\right)$, where $e$ represents student effort, $p$ denotes parental and community interactions, $s$ is school quality, and $x_{1}, \ldots, x_{n}$ are all other inputs to the education production function including stress, homesickness, peer pressure, nutritious foods, positive role models, and so on. We assume that an agent's utility exhibits decreasing marginal returns in achievement $(\theta)$ and leisure $(l)$, and that achievement has decreasing marginal returns on effort. Assuming a student has one unit of time to allocate between effort and leisure, her optimization problem can be written as:

$$
\max _{e \in[0,1]} u\left(f\left(e, p, s, x_{1}, \ldots, x_{n}\right), g(l)\right)
$$


subject to her budget constraint $e+l \leq 1$. The first order condition with respect to $e$ can be written as $\frac{\partial u}{\partial f} \cdot \frac{\partial f}{\partial e}=\frac{\partial u}{\partial g}$, which implies that, when optimizing, the marginal benefit of effort equals the marginal cost of that effort.

Total differentiation of the first order condition with respect to $p$, and collection of terms, gives:

$$
\frac{\partial e}{\partial p}=\frac{-\left(\frac{\partial^{2} u}{\partial f^{2}} \cdot \frac{\partial f}{\partial p} \cdot \frac{\partial f}{\partial e}+\frac{\partial u}{\partial f} \cdot \frac{\partial^{2} f}{\partial p \partial e}\right)}{\frac{\partial^{2} u}{\partial f^{2}} \cdot\left(\frac{\partial f}{\partial e}\right)^{2}+\frac{\partial u}{\partial f} \cdot \frac{\partial^{2} f}{\partial e^{2}}+\frac{\partial^{2} u}{\partial g^{2}}}
$$

Note: Since utility has decreasing marginal returns on achievement and leisure, $\frac{\partial^{2} u}{\partial f^{2}}<0$ and $\frac{\partial^{2} u}{\partial g^{2}}<0$. Similarly, achievement has decreasing marginal returns on effort, so that $\frac{\partial^{2} f}{\partial e^{2}}<0$. We assume that $\left(\frac{\partial f}{\partial e}\right)^{2}>0$ and that achievement has a positive effect on utility, so that $\frac{\partial u}{\partial f}>0$. Putting all of this together, we can conclude that the denominator of (1) is less than zero.

The sign of the numerator, however, could be either positive or negative. We know that $\frac{\partial^{2} u}{\partial f^{2}}<0$ and $\frac{\partial f}{\partial e}>0$ but we cannot sign $\frac{\partial f}{\partial p}$, which could be either positive or negative. If parents are supportive and that support helps a student increase his achievement, then $\frac{\partial f}{\partial p}$ is positive. If, on the other hand, the parent is a negative influence and the parent's involvement hinders a student's achievement, then $\frac{\partial f}{\partial p}$ will be negative. Similarly, while $\frac{\partial u}{\partial f}>0$, the sign of $\frac{\partial^{2} f}{\partial p \partial e}$ can also vary depending on the particular type of interaction that takes place between a student and his parent.

An analogous computation, with respect to $s$, gives

$$
\frac{\partial e}{\partial s}=\frac{-\left(\frac{\partial^{2} u}{\partial f^{2}} \cdot \frac{\partial f}{\partial s} \cdot \frac{\partial f}{\partial e}+\frac{\partial u}{\partial f} \cdot \frac{\partial^{2} f}{\partial s \partial e}\right)}{\frac{\partial^{2} u}{\partial f^{2}} \cdot\left(\frac{\partial f}{\partial e}\right)^{2}+\frac{\partial u}{\partial f} \cdot \frac{\partial^{2} f}{\partial e^{2}}+\frac{\partial^{2} u}{\partial g^{2}}}
$$

Again, the sign of this effect depends on the signs and magnitudes of $\frac{\partial f}{\partial s}$ and $\frac{\partial^{2} f}{\partial s \partial e}$. We assume that higher school quality leads to higher achievement, $\frac{\partial f}{\partial s}>0$, and higher school quality and higher effort interact to produce higher achievement, $\frac{\partial^{2} f}{\partial s \partial e}>0$. Yet, we still cannot definitively conclude whether the numerator is positive or negative, because $\frac{\partial^{2} u}{\partial f^{2}} \cdot \frac{\partial f}{\partial s} \cdot \frac{\partial f}{\partial e}<0$ but $\frac{\partial u}{\partial f} \cdot \frac{\partial^{2} f}{\partial s \partial e}>0$. 
A final computation, with respect to the vector of other inputs $\left\{x_{1}, \ldots x_{n}\right\}$ gives:

$$
\sum_{i=1}^{n} \frac{\partial e}{\partial x_{i}}=\frac{-\sum_{i=1}^{n}\left(\frac{\partial^{2} u}{\partial f^{2}} \cdot \frac{\partial f}{\partial x_{i}} \cdot \frac{\partial f}{\partial e}+\frac{\partial u}{\partial f} \cdot \frac{\partial^{2} f}{\partial x_{i} \partial e}\right)}{\frac{\partial^{2} u}{\partial f^{2}} \cdot\left(\frac{\partial f}{\partial e}\right)^{2}+\frac{\partial u}{\partial f} \cdot \frac{\partial^{2} f}{\partial e^{2}}+\frac{\partial^{2} u}{\partial g^{2}}}
$$

In the context of this model, SEED provides an opportunity to measure the effect of an exogenous shift in the parameters $\left(p, s, x_{i}\right)$, simultaneously, that change as a result of sending a child to a "No Excuses" charter school coupled with a boarding program. We do not have enough variation to isolate the effect of any particular parameter. Rather, the effect that we obtain from the SEED lottery results is approximately the first-order effect

$$
d f=\left(\frac{\partial f}{\partial s}+\frac{\partial f}{\partial e} \cdot \frac{\partial e}{\partial s}\right) d s+\left(\frac{\partial f}{\partial p}+\frac{\partial f}{\partial e} \cdot \frac{\partial e}{\partial p}\right) d p+\sum_{i=1}^{n}\left(\frac{\partial f}{\partial x_{i}}+\frac{\partial f}{\partial e} \cdot \frac{\partial e}{\partial x_{i}}\right) d x_{i}
$$

which could be positive, negative, or neutral. We know that $\frac{\partial f}{\partial s}>0$ and $\frac{\partial f}{\partial e}>0$, but we cannot $\operatorname{sign} \frac{\partial e}{\partial s}, \frac{\partial f}{\partial p}, \frac{\partial e}{\partial p}, \frac{\partial f}{\partial x_{i}}, \frac{\partial e}{\partial x_{i}}$, or even $d x_{i}$. In words, if homesickness, peer pressure, and loss of identity is negligible $\left(x_{i}\right)$, effort increases in school quality, and minimizing parental interactions induces more effort in school, then the effect of attending the SEED schools will be positive. Conversely, if taking students out of their homes and social environments creates stress, loss of identity and homesickness, and these effects outweigh other potentially positive aspects of boarding, then the results can be negative.

To complement Table 2, Appendix Figure 1 shows the geographic distribution of treatment and control students across Washington, D.C., as well as census tract poverty rates. This map confirms that SEED treatment and control students are similarly distributed across space and are more likely to be in higher-poverty areas of the city.

\section{Data and Research Design}

We merge data from two sources: information from files at the SEED school and administrative data on student demographics and outcomes from the District of Columbia Public Schools (DCPS). ${ }^{11}$

\footnotetext{
${ }^{11}$ A small number of students in the SEED lottery have test scores from the Maryland Schools Assessment (MSA), so we make use of these data as well.
} 
The data from SEED consist of lottery files from the 2007 and 2008 lotteries. To insure that all students in our lottery sample have an equal chance of being admitted to SEED, we drop students with a sibling already enrolled in SEED (because they are guaranteed admission). Since siblings who apply together are more likely to get in (if one sibling wins the lottery then all siblings are allowed to enroll), we also include a dummy to indicate the presence of a sibling in the lottery, as well as the interaction of this dummy with year of application. Excluding the applicants with siblings in the same lottery yields results that are almost identical. ${ }^{12}$

A typical student's data from SEED's administrative files contains the applicant's cohort, first and last names, date of birth, whether and how the applicant was offered admission (immediately, off the waitlist, or not at all), whether the applicant already had a sibling attending SEED (and was therefore guaranteed admission), whether the applicant applied late to SEED (and was therefore simply added to the end of the waitlist and not included in the lottery), and, if applicable, date of withdrawal from SEED. The files also include demographic data such as sex, race, free lunch eligibility, special education status, English Language Learner status, and family background variables such as the student's living situation, parents' marital status, and parents' highest level of education (though the data fields for the latter two variables are sparse).

The SEED data were matched to administrative data from the District of Columbia Public Schools (DCPS) collected from 2005-06 through 2008-09 using the maximum information available. Match keys were used in the following order: (1) last name, first name, date of birth with various versions of the names (abbreviations, alternative spellings, hyphenated versus non-hyphenated); (2) last name, first name, and various versions of the date of birth (most often the month and day reversed); (3) last name, first name, prior school, and prior grade with various likely adjustments to prior grade; (4) name, date of birth, and prior grade. Once these match keys had been run, the remaining data were matched by hand considering all available variables. In our final sample, the proportion of students for whom at least one achievement test score was matched is 95 percent for SEED lottery winners $(\mathrm{N}=129)$ and 92 percent for SEED lottery losers $(\mathrm{N}=92)$. Details of the match rates and attrition for each lottery cohort are reported in Table 1. Our match rates and attrition are similar to those from previous work using charter lottery data (Abdulkadiroglu et al., 2009; Dobbie and Fryer, forthcoming; Hoxby and Murarka, 2009; Angrist et al., 2010).

\footnotetext{
${ }^{12}$ No student entered both the 2007 and 2008 lotteries.
} 
The DCPS data contain student-level administrative data on approximately 45,000 students in each year. The data include information on student race, gender, free and reduced-price lunch eligibility, attendance, and math and reading achievement scores in grades three through eight and ten. The math and reading tests, extracted from the District of Columbia Comprehensive Assessment System (DC CAS), are administered each April to students in grades three through eight and ten. The DC CAS exams measure knowledge and skills in reading and math. Students in grades four, seven, and ten also take a composition test; students in grades five and eight take a science test; and students in grades nine through twelve who are enrolled in biology, take a biology test.

In Washington, D.C., all public school students, including those attending charters, are required to take the reading and math tests unless they are medically excused or have a severe disability. Students with moderate disabilities or who are English Language Learners must take both tests, but may be granted special accommodations (additional time, translation services, and so on) at the discretion of school or state administrators.

Summary statistics for the variables that we use in our core specifications, as well as student living situation, are displayed in Table 2. Column 1 includes all students who attended seventh grade in DCPS in 2007-08 and 2008-09, Column 2 restricts the sample to lottery applicants, Columns 3 and 4 are for lottery winners and losers, respectively, and Column 5 further restricts the sample to students who actually enroll in SEED for at least a day. Every student in the SEED lottery sample is black. Males are more likely to be lottery winners than females, but this is due to the fact that the SEED school holds separate lotteries for males and females and receives more applications from females. As Column 6 shows, SEED applicants have higher baseline test scores than DCPS students, on average, but these differences are not significant. SEED applicants are significantly more likely to be eligible for free lunch and significantly less likely to be special education students.

Column 7 of Table 2 reports covariate differences, and their associated standard errors, between lottery winners and losers controlling for lottery fixed effects, sex indicator variables (since separate lotteries are held for males and females), and a contemporaneous sibling dummy as well as the interaction of this dummy with year of application. Lottery winners tend to have slightly higher baseline reading and math scores, but the differences are not statistically significant. Free lunch status and special education status are also balanced among lottery winners and losers. There are 
two marginally significant differences between lottery winners and losers: (1) lottery winners are 8.9\% (s.e. 4.6) less likely to be English Language Learners; and (2) lottery winners are less likely to live with other legal guardians.

\subsection{Research Design}

Our research design exploits the fact that oversubscribed charter schools in Washington, D.C., are required to admit students via random lottery. This allows us to provide a set of causal estimates of the effect of attending the SEED school. Let the effect of attending the SEED school on student achievement be a linear function of the number of years spent at the school $\left(S E E D_{i g t}\right)$. We estimate this effect using the equation

$$
\text { achievement }_{i g t}=\alpha_{t}+\beta_{g}+\delta^{\prime} X_{i}+\rho S E E D_{i g t}+\epsilon_{i g t}
$$

where achievement $t_{i g t}$ denotes the test score of student $i$ tested in grade $g$ in year $t, \alpha_{t}$ and $\beta_{g}$ are year-of-test and grade-of-test effects, and $X_{i}$ is a vector of demographic controls, which include an indicator variable for sex, since separate lotteries were conducted for males and females, as well as baseline test scores in reading and math, free lunch eligibility, special education status, and English Language Learner status. ${ }^{13} \epsilon_{\text {igt }}$ is an error term that captures random variation in test scores.

The causal effect of attending SEED is $\rho$. If the number of years a student spends at SEED were randomly assigned, ordinary least squares estimates of equation (4) would capture the average causal effect of each year spent at SEED. Because students and parents selectively choose whether to enroll in SEED, however, these estimates are likely to be biased by correlation between school choice and unobserved characteristics related to student ability, motivation, or family background.

We identify $\rho$ by comparing the average outcomes of students who "won" the lottery to the average outcomes of students who "lost" the lottery. The lottery losers therefore form the control group corresponding to the counterfactual state that would have occurred for students in the treatment group if they had not been offered a spot in the charter school. We define lottery winners as students who receive a winning lottery number or are offered admission off of the waitlist. Given the size of the estimated treatment effect, our results are robust to other definitions of "lottery

\footnotetext{
${ }^{13}$ All students in the lottery sample are black, so race is not included as a covariate.
} 
winner."

Under several assumptions (that the treatment group assignment is random and that winning the lottery only affects outcomes through SEED enrollment), we can estimate the average effect of treatment for students induced into enrollment by the lottery offer. The parameter is estimated through a two-stage least squares (2SLS) regression of student outcomes on years of enrollment $\left(S E E D_{\text {igt }}\right)$ with the lottery offer as an instrumental variable for enrollment.

The first stage equations for IV estimation take the form:

$$
S E E D_{i g t}=\zeta_{t}+\eta_{g}+\sum_{j} \mu_{j} l_{\text {lottery }} y_{i j}+\iota X_{i}+\pi Z_{i}+\kappa_{i g t}
$$

where the lottery indicators lotter $y_{i j}$ control for which lottery the student entered and $\pi$ captures the effect of the lottery offer $\left(Z_{i}\right)$ on the number of years a student spends at SEED.

\section{The Impact of Attending SEED Schools on Student Achieve- ment}

Table 3 reports lottery results for the pooled sample consisting of the 2007 and 2008 cohorts at the SEED School in Washington, D.C. We report first stage (Column 1), reduced-form (Column 2), and 2SLS estimates (Column 3). There are two panels: the top panel displays the results for reading scores and the bottom panel presents analogous results for math scores. Within each panel, we estimate three specifications of equation (4). The first contains no controls, the second controls for previous year's achievement test scores in both reading and math, and the third specification includes controls for free lunch eligibility, special education status, and English Language Learner status. The outcome variable is seventh grade test scores from both cohorts and eighth grade test scores for the 2007 cohort.

Lottery winners score $0.236(0.100)$ standard deviations (hereafter, $\sigma$ ) higher in reading and $0.384 \sigma(0.116)$ higher in math in the raw data. Controlling for previous scores and demographic variables reduces these effect sizes to $0.188 \sigma(0.087)$ and $0.218 \sigma(0.081)$ in reading and math, respectively. The first stage coefficients are all less than one, which is consistent with other work on "No Excuses" charter schools (Abdulkadiroglu et al., 2009). The 2SLS estimate, which captures 
the causal effect of attending the SEED school for one year for students induced into enrolling by the lottery offer, is $0.198 \sigma(0.093)$ in reading and $0.230 \sigma(0.084)$ in math controlling for previous scores and demographics.

The magnitudes of our estimates in math are similar to those from other "No Excuses" charter schools, which range from $0.26 \sigma$ to $0.54 \sigma$ (Abdulkadiroglu et al., 2009; Angrist et al., 2010; Dobbie and Fryer, forthcoming). The magnitudes of the results in reading, however, are surprising. The literature has typically found treatment effects on reading for middle school-aged or older children, under a host of interventions, to be significantly smaller than in math (Decker et al., 2004; Abdulkadiroglu et al., 2009; Angrist et al., 2010; Dobbie and Fryer, forthcoming; Hoxby and Murarka, 2009). One of the leading theories for this result is that reading scores are influenced by the language spoken during the time when students are outside of the classroom (Charity et al., 2004; Rickford, 1999). Charity et al. (2004) argue that if students speak non-standard English at home and in their communities, increases in reading scores are difficult to effect - especially for older students. The surprising effect of SEED on reading scores is broadly consistent with this point of view.

Tables 4 and 5 explore the heterogeneity of our estimated treatment effects in a variety of subsamples of the data and report p-values for the differences in the treatment effects. Each table reports 2SLS estimates that include baseline scores and demographic controls. Table 4 partitions the data by sex, whether or not a student is eligible for free lunch, and special education status. Perhaps the most striking result is that the positive treatment effects in reading and math from attending SEED are driven almost entirely by the female lottery applicants. (An important caveat is that we are under-powered to detect whether there are modest positive effects for males.) The 2SLS estimates for females (including controls for baseline scores and demographic characteristics) are $0.382 \sigma$ in reading $(-0.138 \sigma$ for males $)$ and $0.265 \sigma$ in math $(0.037 \sigma$ for males). The difference between males and females is significant for reading, but we cannot reject the null hypothesis that the effects are the same for math. ${ }^{14}$ Students eligible for free lunch experienced larger effects than students who are not eligible for free lunch, and this difference is nearly marginally significant for reading. Estimated effects are also slightly larger for students who are not in special education compared to students who are in special education, but large standard errors prevent sharp conclusions.

\footnotetext{
${ }^{14}$ These results are similar to the gender differences found in the Moving to Opportunity experiment (Kling et al., 2007), which suggests that removing students from their home environment may be particularly bad for boys.
} 
Table 5 examines whether the effects of SEED on achievement differ as a function of a student's pre-treatment test score, both by examining the effects of SEED for students above and below the median of the previous year test score, and by estimating a model that adds the interaction between baseline score and an indicator for winning the SEED lottery as an additional instrument. The results suggest that lower-ability students benefit more from SEED. Students with below-median baseline scores gained $0.314 \sigma(0.140)$ in reading, which is significantly different from the effects for students who are above the median when they enter SEED (-0.048 $\sigma(0.081))$. Similarly, students with below-median baseline scores showed gains of $0.354 \sigma(0.129)$ in math, compared to $0.163 \sigma$ (0.118) for students with above-median baseline scores - but due to low power we are unable to distinguish between these two point estimates.

The estimates from the baseline score interaction model also suggest that SEED may have larger effects for lower-ability students, but, again, coefficients are too imprecisely estimated to make definitive conclusions. The interaction terms for reading and math are $-0.112 \sigma$ and $-0.084 \sigma$, respectively, which suggest that a student who is $0.5 \sigma$ below the mean in terms of ability (as measured by baseline test score) would gain an additional $0.056 \sigma$ in reading and $0.042 \sigma$ in math per year. These interaction term coefficients are very similar to those reported by Angrist et al. (2010) for the effects of attending a "No Excuses" charter school in Lynn, Massachusetts, on students of lower baseline ability. Still, our estimates should be interpreted with caution given the lack of power.

Our lottery estimates use the sample of students for which we have post-lottery scores. If lottery winners and losers have different rates of selection into this sample, our results may be biased. Table 6 compares the rates of attrition of lottery winners and lottery losers. In the pooled sample, 86.1 percent of winners and 87.9 percent of losers have reading scores. A simple test for selection bias is to investigate the impact of the lottery offer on the probability of entering our lottery sample. The results of this test are reported in Columns 3 through 5 of Table 6 - the difference is statistically zero. Similarly, 86.1 percent of winners and 86.4 percent of losers have math scores, and this difference is also statistically zero. This suggests that differential attrition is not likely to be a concern in interpreting the results. 


\section{Discussion}

Our lottery estimates reveal that SEED is effective at increasing achievement among poor minority students. Students who enroll in SEED increase their achievement by 0.198 standard deviations in reading and 0.230 standard deviations in math, per year. Thus, SEED schools have the power to eliminate the racial achievement gap in four years.

Let us put the magnitude of our estimates in perspective. The effect of lowering class size from 24 to 16 students per teacher is approximately $0.22 \sigma(0.05)$ on combined math and reading scores (Krueger, 1999). While a one-standard deviation increase in teacher quality raises math achievement by $0.15 \sigma$ to $0.24 \sigma$ per year and reading achievement by $0.15 \sigma$ to $0.20 \sigma$ per year (Rockoff, 2004; Hanushek and Rivkin, 2005; Aaronson et al., 2007; Kane et al., 2008), value added measures are not strongly correlated with observable characteristics of teachers, making it difficult to identify the best teachers ex ante. The effect of Teach for America, one attempt to bring more skilled teachers into poorly performing schools, is $0.15 \sigma$ in math and $0.03 \sigma$ in reading (Decker et al., 2004). The effect of Head Start is $0.147 \sigma(0.103)$ in applied problems and $0.319 \sigma(0.147)$ in letter identification on the Woodcock-Johnson exam, but the effects on test scores fade in elementary school (Currie and Thomas, 1995; Ludwig and Phillips, 2007).

These effect sizes are a small fraction of the impact of attending SEED. An emerging literature on "No Excuses" charter schools finds effect sizes closest to our own. ${ }^{15}$ Abdulkadiroglu et al. (2009) and Angrist et al. (2010) find effect sizes similar to ours, with students enrolled in a set of Boston area "No Excuses" charter middle schools gaining about $0.4 \sigma$ per year in math and $0.1 \sigma$ per year in reading. Dobbie and Fryer (forthcoming) report that the impact of attending the Harlem Children's Zone's middle schools is $0.26 \sigma$ in math and $0.05 \sigma$ in reading. The key difference is that SEED schools increase reading scores more than the typical "No Excuses" charter.

As the Obama administration and other governments around the U.S. decide whether and how to use urban boarding schools as a model to increase achievement among the poor, cost is an important consideration. At the SEED School in Washington, D.C., about $\$ 39,275$ is spent per pupil per year, compared to $\$ 20,523$ per student in District of Columbia Public Schools (DCPS). ${ }^{16}$

\footnotetext{
${ }^{15}$ The fact that "No Excuses" charter schools coupled with a boarding option increases achievement similar to "No Excuses" charter schools without boarding is consistent with the evidence on neighborhood effects described in Kling et al. (2007).

${ }^{16}$ See Appendix C for details of per pupil expenditure figures.
} 
Therefore, a natural question arises for policymakers: is the extra $\$ 18,752$ per student per year a good investment? To answer this, we conclude with a simple cost-benefit analysis, comparing the total net present value of costs and net present value of benefits of attending SEED.

Let $C_{t}$ denote the additional cost of SEED per pupil in year $t$, above normal DCPS costs, and let $r$ be the real discount rate. If $t=1$ corresponds to the student's sixth grade year, the present value of the costs of SEED can therefore be written as

$$
\text { Present Value of Costs }=\sum_{t=1}^{3} \frac{C_{t}}{(1+r)^{t}} .
$$

For the 2007 and 2008 cohorts, admitted students were enrolled, on average, for about 77.5 percent of the time they could have potentially been enrolled in SEED. This means that one would expect them to spend about 2.33 years actually enrolled in SEED. From this, we can infer that $C_{1}=C_{2}=$ $\$ 18,752$ and $C_{3}=.33 \cdot \$ 18,752=\$ 6,188$.

Calculating the gain in lifetime earnings associated with increased achievement requires a few additional assumptions. Adopting the framework used in Krueger (2003), we let $E_{t}$ represent an individual's average real earnings each year after entering the labor market at age 18. We let $\beta$ represent the increase in earnings associated with a one-standard deviation increase in either reading or math achievement scores. As is discussed in Krueger (2003), the literature suggests that $\beta$ is approximately 8 to 12 percent. $^{17}$

Let $\delta_{R}$ and $\delta_{M}$ be the increase in test scores in reading and math, respectively (in standard deviation units), as a result of attending SEED. Furthermore, assume that each individual works until age 65 . The present value of the benefits from these increased earnings would be

$$
\text { Present Value of Benefits }=\sum_{t=7}^{54} E_{t} \cdot \frac{\beta\left(\delta_{R}+\delta_{M}\right)}{(1+r)^{t}}
$$

Thus, SEED's internal rate of return can be calculated as the discount rate, $r^{*}$, that solves:

$$
\sum_{t=1}^{3} \frac{C_{t}}{(1+r)^{t}}=\sum_{t=7}^{54} E_{t} \cdot \frac{\beta\left(\delta_{R}+\delta_{M}\right)}{(1+r)^{t}}
$$

We use values of average annual earnings by age group from the 2009 Current Population Survey

\footnotetext{
${ }^{17}$ See Appendix $\mathrm{C}$ for more details.
} 
for $E_{t}$. However, students who entered SEED in 2007 will enter the labor market in 2013, and real earnings will likely grow substantially between 2009 and 2013. If $\gamma$ is the rate of productivity growth, then we can account for this growth by multiplying $E_{t}$ by $(1+\gamma)^{t-4}$ in our above equations. As in Krueger (2003), we note that real earnings and productivity have grown by about 1 to 2 percent per year, so that these are plausible values for $\gamma$.

The top panel of Table 7 presents discounted present values of benefits and costs for SEED under various assumptions for the values of $r$ and $\gamma$. If we assume no annual productivity growth, the return on investment in SEED is 4.38 percent. If annual productivity growth is 1 percent or 2 percent, the return on investment is 4.59 percent or 4.80 percent, respectively. Here, for the sake of comparison, we think of SEED as a middle-school intervention serving grades six through eight. ${ }^{18}$ If we assume instead that SEED is a six-year intervention (from grades seven through twelve), that SEED students therefore would attend for approximately 4.7 years, and that SEED students experience constant gains each year, then the estimated internal rates of return are slightly higher; they are 4.80 percent, 4.99 percent, and 5.18 percent, assuming annual productivity growth rates of 0 percent, 1 percent, and 2 percent, respectively.

For comparison, the bottom panel of Table 7 presents similar estimates for costs and benefits for "No Excuses" charter schools. To do this, we make use of lottery estimates from an analysis of Boston area charter schools in Abdulkadiroglu et al. (2009). ${ }^{19}$ Under the assumptions that $\beta$ is 8 percent and $\gamma$ is 1 percent, we find that the return on investment of a "No Excuses" charter schools is 18.50 percent - approximately four times the return of SEED schools.

There are two important caveats to our cost-benefit analysis. First, and most important, we restrict our attention to expected future income that may increase as a result of an increase in test scores and do not consider other important social outcomes. We do this because we have plausible estimates of the effect of increasing achievement on lifetime earnings from a variety of sources. There is evidence from several literatures that suggests higher achievement is correlated with other outcomes such as lower crime rates (Levitt and Lochner, 2001), lower incarceration rates (Neal and Johnson, 1996), better health outcomes and lower mortality (Lleras-Muney, 2005), and so on. We do not attempt to compute monetary benefits accrued from these effects for two reasons: (1)

\footnotetext{
${ }^{18}$ Even though the SEED School of Washington, D.C., admitted students in seventh grade in 2007 and 2008 , as opposed to sixth grade, thinking of SEED as an intervention in grades six through eight makes the comparison with "No Excuses" charters cleaner, and qualitative results are not sensitive to this assumption.

${ }^{19}$ See Appendix $\mathrm{C}$ for a discussion of how the costs per pupil were derived.
} 
the private value of income is clear, but we did not want to make assumptions about the benefits of improving other social outcomes such as incarceration, teen pregnancy, and so on; and (2) we are more confident that more education causes higher income than we are that more education causes these other social outcomes. Note: Even if we made an educated guess about the benefits that would accrue through these channels, our main qualitative conclusion - the marginal benefit of boarding, beyond a "No Excuses" school, is outweighed by the cost - would be unchanged as those benefits are also present for "No Excuses" schools that do not have a boarding option. For the conclusions of our cost-benefit analysis to change, there must be important benefits unique to urban boarding schools that are not captured in test scores (e.g. reduced teen pregnancy rates, lowering of discount rates, or increased grit and determination). Whether or not this is true is beyond the scope of this paper, but knowable in the fullness of time.

Second, Chetty et al. (2010) suggest that long-term benefits of a high-quality education may operate through non-test score outcomes not easily observed. If urban boarding schools influence this set of outcomes - discount rates, for instance - then we may be underestimating the long-term benefits. Given that we have no evidence in favor or against this hypothesis, it is an open question. 


\section{NOT FOR PUBLICATION}

\section{Online Appendix A: SEED Program Details}

The SEED (School for Educational Evolution and Development) Foundation was founded in 1997 and opened its first school in Washington, D.C., in the fall of 1998. The school enrolled 40 seventh graders in its inaugural year and differs from other charter schools in a significant way: the SEED School is an urban public boarding school. From Sunday night through Friday afternoon, students live on campus, returning home for 48 hours every weekend.

The impetus for the creation of SEED was the idea that the educational opportunities of many urban students are hindered both by failing public schools and by neighborhood risks and distractions that divert attention from educational pursuits. The founders of SEED believed that an urban boarding school could remove the dangerous distractions of the urban neighborhoods from which its students hailed, and provide its students with added support and activities during the after-school hours when traditional public schools send students home.

The school was originally housed in the attic of the Capital Children's Museum before moving in 2001 to its current location in Washington, D.C.'s impoverished Ward 7. The campus, which is on the site of a former public school, consists of an academic building, two dormitories (one male and one female), and a student center. The size of the student body has expanded from the original 40 seventh graders to now serve 320 students from sixth through twelfth grades.

The SEED Foundation opened its second school in the fall of 2008, located in Baltimore but open to students throughout Maryland. The Maryland school currently serves 160 students in sixth and seventh grades and will expand to serve 400 students in grades six through twelve. The school has a campus layout similar to that of the Washington, D.C., campus, with dormitory buildings, academic buildings, and recreational facilities. The major difference between the two campuses is size: the Washington, D.C., campus is four acres, while the Maryland campus is fifty-two acres and shares land with a natural preservation area.

Both schools admit students by a lottery if more students apply than there are spots available. To enter the lottery, students and their parents must complete a thorough application and prove eligibility for the lottery, including proof of residency and age eligibility. In order to promote 
geographic diversity, the SEED School of Maryland reserves a spot for one student from each county from which an eligible student applies.

Because of the boarding aspect of the program, the schools are much more expensive to operate than traditional public schools, or even more highly funded charter schools (such as the Harlem Children's Zone). In 2008, the District of Columbia Public Schools spent approximately $\$ 20,523$ per pupil; SEED's expenditures were around $\$ 39,275$ per pupil.

\section{Academic Program}

The academic component of the SEED model is broken into two basic pieces, the middle school program and the high school program. The middle school curriculum is focused on basic skills with the goal of allowing all students to enter the high school program performing at or above grade level. The benchmark standards that middle school students must master before promotion to high school are referred to as the "Gate." In order to help students meet the goals of the Gate, students are provided with tutoring outside of the classroom and extra periods of instruction. Students who need more time to master grade level skills can take a "growth year" during middle school. The middle school curriculum utilizes a readers and writers workshop model for language arts instruction and is designed such that all students will take algebra by eighth grade.

The high school curriculum is a college-preparatory program of studies for all students. To graduate, students must complete four years of English, four years of mathematics (through at least Algebra II), three years of social studies, three years of science, three years of a foreign language, one and a half years of physical education and health, one year of arts, one half year each of U.S. government and politics, Washington, D.C., history, and technology, as well as five and a half years' worth of elective courses. In addition to course requirements, students must also take the SAT or ACT college admissions test, apply to at least five colleges or universities, and complete sixty hours of community service in order to graduate. The school offers Advanced Placement courses in English Literature, English Language, U.S. History, Government, and Biology.

Both the Washington, D.C., and Maryland schools at the middle and high school levels have an extended school day, from 8 a.m. until 4 p.m., and provide students with extensive after-school tutoring as needed. Instruction within the schools relies heavily on data. The SEED schools use internal interim assessments and have data days every quarter for the staff (both academic and 
boarding) to review student data. There is a strong emphasis on preparation for college from the time the students enter the school that begins more informally in middle school and is a formal part of the curriculum in high school. While the SEED schools are only open for a traditional school year, SEED staff try to place students in educational programs during the summer months.

\section{Residential Program}

From Sunday evening through Friday afternoon, students live on campus, in double bedrooms in same-sex dorms. Students are organized into "houses" of 12-14 students within the dormitories. The houses are all named for a college or university and have study hall and meal times together, as well as other activities such as book clubs, field trips, and community service. The school offers athletic and other extracurricular activities to students after school hours, as well as a program known as HALLS (Habits for Achieving Life-Long Success) that teaches students study skills, time management, and interpersonal communication. Students can complete homework in their dorm rooms or in one of the common study spaces available throughout the dormitory. There is a computer in each dorm room as well as in the common areas and the residential staff are available during homework times to answer questions. The residential staff is separate from the school faculty, although the two groups interact often to discuss student progress.

Despite the fact that students are living away from their families for the majority of the week, SEED offers some opportunities for parental involvement. SEED holds community dinners and gives parents the opportunity to serve as tutors during study hall, assist during extracurricular activities, and participate in book clubs. 


\section{NOT FOR PUBLICATION}

\section{Online Appendix B: Data Description}

\section{SEED}

The data obtained from the SEED School in Washington, D.C., include lists of lottery applicants in 2007 and 2008 and whether or not they were admitted immediately, as well as call logs documenting the calls made to candidates on the waitlist. Data also include SEED enrollment lists from each year, as well as a number of other administrative files.

A typical student's data from SEED's administrative files contains the applicant's cohort, first and last names, date of birth, whether and how the applicant was offered admission (immediately, off the waitlist, or not at all), whether the applicant already had a sibling attending SEED (and was therefore guaranteed admission), whether the applicant applied late to SEED (and was therefore simply added to the end of the waitlist and not included in the lottery), and, if applicable, date of withdrawal from SEED. The files also include demographic data such as sex, race, free lunch eligibility, special education status, English Language Learner status, and family background variables such as the student's living situation, parents' marital status, and parents' highest level of education (though the data fields for the latter two variables are sparse). The files were used to compile a list of lottery applicants with their lottery outcomes and enrollment statuses. This list was examined by SEED officials, who used applicant records (such as copies of original SEED applications) to resolve discrepancies.

In addition, other administrative files that were provided by SEED contained lottery registration data, such as students' addresses, parents' names, previous school attended, and reasons for applying to SEED. The address data were used in conjunction with last names to determine siblings who registered for the same lottery.

\section{District of Columbia Public Schools}

District of Columbia Public Schools (DCPS) administrative data were collected for school years from 2005-06 through 2008-09. These files contain scores from the District of Columbia Comprehensive Assessment System (DC CAS) and enrollment files containing information on the school and grade 
level of each student in DCPS as well as demographic information such as race, sex, free lunch eligibility, special education status, and English Language Learner status. In addition, enrollment files contain last name, first name, and date of birth, which were used to match students to SEED data. Furthermore, all students in DCPS data are assigned a unique identifier called the "pupil number." This identifier was available for many students in the SEED data, as well.

In Washington, D.C., all public school students, including those attending charters, are required to take the reading and math tests unless they are medically excused or have a severe disability. Students with moderate disabilities or who are English Language Learners must take both tests, but may be granted special accommodations (additional time, translation services, and so on) at the discretion of school or state administrators. The DC CAS is administered each April to students in grades 3 through 8 and 10. It measures knowledge and skills in reading and math. Students in grades 4,7 , and 10 also take a composition test; students in grades 5 and 8 also take a science test; and students in grades 9 through 12 who take biology also take a biology test. 


\section{NOT FOR PUBLICATION}

\section{Online Appendix C: Cost-Benefit Analysis}

\section{Calculating Costs}

According to an audited DCPS enrollment file, there were 329 students enrolled in the SEED School of Washington, D.C., as of October 6, 2008. According to the SEED School of Washington, D.C.'s financial report for the 2008-09 fiscal year, SEED's total expenses were $\$ 12,921,449$. This amounts to $\$ 39,275$ per student.

According to the National Center for Education Statistics (NCES), total expenditures per pupil in the District of Columbia Public Schools were $\$ 20,596$ in 2007-08 dollars for the 2006-07 school year. This figure is obtained from Table 186 of the NCES's List of 2009 Digest Tables, which can be found at the following web site: http://nces.ed.gov/programs/digest/2009menu_tables.asp. Assuming similar expenditures for 2008-09, this amounts to $\$ 20,523$ per student in 2009 dollars.

\section{Calculating Benefits}

Using evidence from the British National Child Development Study, Currie and Thomas (2001) find that students who score in the upper quartile of the reading exam earn 20 percent more than students who score in the lower quartile, while students who score in the upper quartile of the math exam earn 19 percent more than students who score in the lower quartile. Following Krueger (2003) and assuming a normal distribution of test scores, we can assume that the average score for the top quartile is about 2.5 standard deviations higher than the average score for the bottom quartile, so that a one-standard deviation increase in reading scores is associated with 8.0 percent higher earnings at age 33. A similar calculation reveals that a one-standard deviation increase in math scores is associated with 7.6 percent higher earnings at age 33 .

Using the National Longitudinal Survey of Youth, Neal and Johnson (1996) find that a onestandard deviation increase in scores on the Armed Forces Qualification Test (AFQT) taken at age 15-18 (and adjusted for age at time of test) is associated with 20 percent higher earnings for both men and women. As Krueger (2003) points out, the differences in these two sets of estimates can be reconciled by the fact that Neal and Johnson (1996) estimate the effect of one achievement 
score, whereas Currie and Thomas (2001) include both reading and math achievement scores in their wage equation. ${ }^{20}$ Because the estimates obtained by Currie and Thomas (2001) are therefore consistent with those of Neal and Johnson (1996), and because estimates from SEED as well as other charter schools are generally presented in terms of achievement gains in reading and math, we rely on the estimates from Currie and Thomas (2001) for our calculations of earnings gains, and assume that the increase in wages associated with a one-standard deviation increase in either reading or math is approximately 8 percent.

\section{Cost-Benefit Analysis of "No Excuses" charter schools}

The middle school lottery sample studied by Abdulkadiroglu et al. (2009) consists of lottery applicants from five Boston middle school charters: Academy of the Pacific Rim, Boston Collegiate, Boston Preparatory, Edward Brooke, and Roxbury Preparatory.

According to the 2008-09 Annual Report of the Academy of the Pacific Rim Charter Public School, its enrollment was 474 students as of October 1, 2008. Its total expenses were $\$ 6,209,015$. This amounts to $\$ 13,099$ per student. According to the 2008-09 Annual Report of the Boston Collegiate Charter School, its enrollment was 464 students as of October 1, 2008. Its total expenses were $\$ 6,362,511$. This amounts to $\$ 13,712$ per student. According to the 2008-09 Annual Report of the Boston Preparatory Charter Public School, it served 285 students in 2008-09. Its total expenses were $\$ 4,330,023$. This amounts to $\$ 15,193$ per student. According to the 2008-09 Annual Report of Edward W. Brooke Charter School, its enrollment was 398 students as of October 1, 2008 and its total expenses were $\$ 5,440,177$. This amounts to $\$ 13,669$ per student. The 2008-09 Annual Report of the Roxbury Preparatory Charter School was unavailable at the time this was written, so we used figures from the 2007-08 Annual Report instead, and converted these figures to 2009 dollars to make them comparable to the figures from other schools. According to the 2007-08 report, 2007-08 enrollment was 198 students, and total expenses were $\$ 3,095,996$. This amounts to $\$ 15,636$ per student. Converting to 2009 dollars, this is $\$ 15,580$. An average of the expenses per student across these five schools yields expenditures of approximately $\$ 14,251$ per student.

According to a Boston Public Schools fact sheet from 2009-10, the school district per pupil

\footnotetext{
${ }^{20}$ Some of the difference can also be attributed to the fact that students studied by Neal and Johnson (1996) are older at the time of their exam, and that British and American labor markets are different.
} 
expenditures for Regular Education for the 2009 Fiscal Year were approximately $\$ 11,755$. With the inclusion of special education instruction costs, the per pupil expenditures are closer to $\$ 14,000$ per student. However, since many critics charge that charter schools do not have to spend as much money to accommodate special education students, we use the $\$ 11,755$ figure to give a more conservative estimate of the returns for the Boston charters.

\section{References}

Aaronson, D., L. Barrow, And W. Sander (2007): "Teachers and Student Achievement in the Chicago Public High Schools," Journal of Labor Economics, 25, 95-135.

Abdulkadiroglu, A., J. D. Angrist, S. M. Dynarski, T. J. Kane, and P. A. Pathak (2009): “Accountability and Flexibility in Public Schools: Evidence from Boston's Charters and Pilots," NBER Working Paper, 15549.

Adams, D. W. (1988): "Fundamental Considerations: The Deep Meaning of Native American Schooling, 1880-1900," Harvard Educational Review, 58 (1), 1-28. (1995): Education for Extinction: American Indians and the Boarding School Experience, Lawrence, KS: University Press of Kansas.

Ainsworth, J. (2002): "Why Does It Take a Village? The Mediation of Neighborhood Effects on Educational Achievement," Social Forces, 81, 117-152.

Angrist, J. D., S. M. Dynarski, T. J. Kane, P. A. Pathak, and C. R. Walters (2010): "Who Benefits from KIPP?" NBER Working Paper, 15740.

Arieli, M., J. Beker, And Y. Kashti (2001): "Residential Group Care as a Socializing Environment: Toward a Broader Perspective," in Child and Youth Care Forum, vol. 30, 403-414.

Barnes, G. and M. Farrell (1992): "Parental Support and Control as Predictors of Adolescent

Drinking, Delinquency, and Related Problem Behaviors," Journal of Marriage and the Family, $54,763-776$. 
Bloom, H. S., S. L. Thompson, R. Unterman, C. Herlihy, and C. F. Payne (2010): “Transforming the High School Experience: How New York City's New Small Schools Are Boosting Student Achievement and Graduation Rates," MDRC.

Brooks-Gunn, J., G. Duncan, and N. Maritato (1999): "Poor Families, Poor Outcomes: The Well-Being of Children and Youth," in Consequences of Growing Up Poor, Russell Sage Foundation, 1-17.

Brooks-Gunn, J. And L. Markman (2005): "The Contribution of Parenting to Ethnic and Racial Gaps in School Readiness," The Future of Children, 15, 139-168.

Cave, G., H. Bos, F. Doolittle, and C. Toussaint (1993): "JOBStaRT: Final Report on a Program for School Dropouts," Manpower Demonstration Research Corporation.

Charity, A., H. Scarborough, and D. Griffin (2004): "Familiarity with School English in African American Children and Its Relation to Early Reading Achievement," Child Development, $75,1340-1356$.

Chetty, R., J. Friedman, N. Hilger, E. Saez, D. W. Schanzenbach, and D. Yagan (2010): "How Does your Kindergarten Classroom Affect Your Earnings? Evidence from Project STAR," NBER Working Paper, 16381.

Chilcoat, H. And J. Anthony (1996): "Impact of Parent Monitoring on Initiation of Drug Use through Late Childhood," Journal of the American Academy of Child and Adolescent Psychiatry, $35,91-100$.

Cookson, P. And C. Persell (1985): "English and American Residential Secondary Schools: A Comparative Study of the Reproduction of Social Elites," Comparative Education Review, 29, 283-298.

Currie, J. And D. Thomas (1995): “Does Head Start Make a Difference?" American Economic Review, 85, 341-364.

(2001): "Early Test Scores, Socioeconomic Status, School Quality and Future Outcomes," in Research in Labor Economics, ed. by S. Polachek and K. Tatsiramos, Emerald Group Publishing Limited, 103-132. 
Datcher, L. (1982): "Effects of Community and Family Background on Achievement," The Review of Economics and Statistics, 64, 32-41.

Datnow, A. And R. Cooper (1997): "Peer Networks of African American Students in Independent Schools: Affirming Academic Success and Racial Identity," Journal of Negro Education, 66, $56-72$.

Decker, P., D. Mayer, And S. Glaserman (2004): "The Effects of Teach for America on Students: Findings from a National Evaluation," Mathematica Policy Research Report, 8792750.

Dick, R., S. Manson, and J. Beals (1993): "Alcohol Use among Male and Female Native American Adolescents: Patterns and Correlates of Student Drinking in a Boarding School," Journal of Studies on Alcohol, 54, 172-177.

Dishion, T. And R. McMahon (1998): "Parental Monitoring and the Prevention of Child and Adolescent Problem Behavior: A Conceptual and Empirical Formulation," Clinical Child and Family Psychology Review, 1, 61-75.

Dobbie, W. And R. Fryer (forthcoming): "Are High-Quality Schools Enough to Increase Achievement among the Poor? Evidence from the Harlem Children's Zone," American Economic Journal: Applied Economics.

Duncan, G. And K. Magnuson (2005): "Can Family Socioeconomic Resources Account for Racial and Ethnic Test Score Gaps?" The Future of Children, 15, 35-54.

Ellis, C. (1996): To Change Them Forever: Indian Education at the Rainy Mountain Boarding School, 1893-1920, University of Oklahoma Press.

Fisher, S., N. Frazer, and K. Murray (1984): "The Transition from Home to Boarding School: A Diary-Style Analysis of the Problems and Worries of Boarding School Pupils," Journal of Environmental Psychology, 4, 211-221.

(1986): "Homesickness and Health in Boarding School Children," Journal of Environmental Psychology, 6, 35-47. 
Fisher, S., K. Murray, And N. Frazer (1985): "Homesickness, Health and Efficiency in First Year Students," Journal of Environmental Psychology, 5, 181-195.

Fordham, S. And J. OGbu (1986): "Black Students' School Success: Coping with the Burden of 'Acting White'," The Urban Review, 18, 176-206.

Fryer, R. (2010a): "Financial Incentives and Student Achievement: Evidence from Randomized Trials," NBER Working Paper, 15898.

- (2010b): "School-Based Merit Pay: An Experiment in 200 New York City Public Schools," Working Paper, Harvard University.

— (forthcoming): "Racial Inequality in the 21st Century: The Declining Significance of Discrimination," Handbook of Labor Economics Volume 4.

Fryer, R. And P. Torelli (2010): "An Empirical Analysis of 'Acting White'," Journal of Public Economics, 94, 380-396.

Gleason, P., M. Clark, C. Tuttle, E. Dwoyer, and M. Silverberg (2010): "The Evaluation of Charter School Impacts," National Center for Education Evaluation and Regional Assistance, Institute of Education Sciences, U.S. Department of Education.

Gonzales, N., A. Cauce, R. Friedman, and C. Mason (1996): "Family, Peer, and Neighborhood Influences on Academic Achievement among African-American Adolescents: One-Year Prospective Effects," American Journal of Community Psychology, 24, 365-387.

Hanushek, E. And S. Rivkin (2005): "Teachers, Schools and Academic Achievement," Econometrica, 73(2), 417-458.

Hoxby, C. M. and S. Murarka (2009): "Charter Schools in New York City: Who Enrolls and How They Affect Their Students' Achievement," NBER Working Paper, 14852.

Jacob, B. And L. Lefgren (2004): "Remedial Education and Student Achievement: A Regression-Discontinuity Analysis," Review of Economics and Statistics, 86(1), 226-244.

(2009): "The Effect of Grade Retention on High School Completion," Center for Local, State, and Urban Policy Working Paper, 12. 
Kahane, R. (1988): "Multicode Organizations: A Conceptual Framework for the Analysis of Boarding Schools," Sociology of Education, 61, 211-226.

Kane, T. J., J. Rockoff, And D. Staiger (2008): "What Does Certification Tell Us about Teacher Effectiveness? Evidence from New York City," Economics of Education Review, 27(6), 615-631.

Kemper, T. (1968): "Reference Groups, Socialization and Achievement," American Sociological Review, 33, 31-45.

Kleinfeld, J. And J. Bloom (1977): "Boarding Schools: Effects on the Mental Health of Eskimo Adolescents," American Journal of Psychiatry, 134, 411-417.

Kling, J., J. Liebman, And L. Katz (2007): "Experimental Analysis of Neighborhood Effects," Econometrica, 75, 83-119.

Koss, M., N. Yuan, D. Dightman, R. Prince, M. Polacca, B. Sanderson, and D. GoldMAN (2003): "Adverse Childhood Exposures and Alcohol Dependence among Seven Native American Tribes," American Journal of Preventive Medicine, 25, 238-244.

Krueger, A. B. (1999): "Experimental Estimates of Education Production Functions," The Quarterly Journal of Economics, 114, 497-532.

_ (2003): "Economic Considerations and Class Size," The Economic Journal, 113, F34-F63.

Krueger, A. B. And D. M. Whitmore (2001): "The Effect of Attending a Small Class in the Early Grades on College-Test Taking and Middle School Test Results: Evidence from Project STAR," The Economic Journal, 111, 1-28.

LaFromboise, T., H. Coleman, and J. Gerton (1998): "Psychological Impact of Biculturalism," Readings in Ethnic Psychology, 123-155.

Leventhal, T. And J. Brooks-Gunn (2000): "The Neighborhoods They Live In: The Effects of Neighborhood Residence on Child and Adolescent Outcomes," Psychological Bulletin, 126, 309-337. 
Levine, S. (1980): "The Rise of American Boarding Schools and the Development of a National Upper Class," Social Problems, 28, 63-94.

Levitt, S. And L. Lochner (2001): "The Determinants of Juvenile Crime," in Risky Behavior Among Youths: An Economic Analysis, ed. by J. Gruber, University of Chicago Press, 327-373.

Lleras-Muney, A. (2005): "The Relationship between Education and Adult Mortality in the United States," Review of Economic Studies, 72, 189-221.

Lotke, E. (1998): "Hobbling a Generation: Young African American Men in Washington, DC's Criminal Justice System - Five Years Later," Crime \& Delinquency, 44, 355.

Ludwig, J. And D. Phillips (2007): "The Benefits and Costs of Head Start," NBER Working Paper, 12973.

Mallar, C. (1982): "Evaluation of the Economic Impact of the Job Corps Program. Third Follow-up Report," Employment and Training Administration (DOL), Washington, D.C. Office of Policy, Evaluation and Research.

Mickelson, R. (1990): "The Attitude-Achievement Paradox among Black Adolescents," Sociology of Education, 63, 44-61.

Neal, D. And W. Johnson (1996): "The Role of Premarket Factors in Black-White Wage Differentials," Journal of Political Economy, 104, 869-895.

Podgursky, M. J. And M. G. Springer (2007): "Teacher Performance Pay: A Review," Journal of Policy Analysis and Management, 26(4), 909-950.

Puma, M., S. Bell, R. Cook, And C. Heid (2010): "Head Start Impact Study: Final Report," Administration for Children and Families.

Raymond, M. (2009): "Multiple Choice: Charter School Performance in 16 States," Center for Research on Education Outcomes (CREDO) Report.

Rickford, J. (1999): African American Vernacular English: Features, Evolution, Educational Implications, Wiley-Blackwell. 
Rockoff, J. E. (2004): "The Impact of Individual Teachers on Student Achievement: Evidence from Panel Data," American Economic Review, 94(2), 247-252.

Rosen, B. (1956): "The Achievement Syndrome: A Psychocultural Dimension of Social Stratification," American Sociological Review, 21, 203-211.

Rothstein, R. (2004): Class and Schools: Using Social, Economic, and Educational Reform to Close the Achievement Gap, Washington, D.C.: Economic Policy Institute.

Wacquant, L. And W. Wilson (1989): "The Cost of Racial and Class Exclusion in the Inner City," The Annals of the American Academy of Political and Social Science, 501, 8-25.

Whitman, D. (2008): Sweating the Small Stuff: Inner-City Schools and the New Paternalism, Washington, D.C.: Thomas B. Fordham Foundation \& Institute.

Zimmer, R., B. Gill, K. Booker, S. Lavertu, T. Sass, And J. Witte (2009): Charter Schools in Eight States: Effects on Achievement, Attainment, Integration, and Competition, RAND Corporation.

Zweigenhaft, R. (1992): "The Application of Cultural and Social Capital: A Study of the 25th Year Reunion Entries of Prep School and Public School Graduates of Yale College," Higher Education, 23, 311-320. 
Table 1: Lottery and Match Summary

\begin{tabular}{lcc}
\hline \hline \multicolumn{3}{c}{ A. Lottery Records } \\
\cline { 2 - 3 } & \multicolumn{2}{c}{ Lottery Cohort } \\
\cline { 2 - 3 } & 2007 & 2008 \\
\cline { 2 - 3 } & 155 & 106 \\
Total number of records & 138 & 94 \\
Excluding siblings & 133 & 91 \\
Excluding late/non-randomized applicants & 132 & 89 \\
\hline
\end{tabular}

B. Match Summary

\begin{tabular}{ccccccccc}
\hline $\begin{array}{c}\text { Lottery } \\
\text { Grade }\end{array}$ & $\begin{array}{c}\text { Lottery } \\
\text { Year }\end{array}$ & $\begin{array}{c}\text { Grades } \\
\text { Observed }\end{array}$ & $\begin{array}{c}\text { Number of } \\
\text { Applicants }\end{array}$ & $\begin{array}{c}\text { Overall } \\
\text { Match Rate }\end{array}$ & $\begin{array}{c}\text { Number of } \\
\text { Winners }\end{array}$ & $\begin{array}{c}\text { Winner } \\
\text { Match Rate }\end{array}$ & $\begin{array}{c}\text { Number of } \\
\text { Losers }\end{array}$ & $\begin{array}{c}\text { Loser } \\
\text { Match Rate }\end{array}$ \\
\hline 7th & 2007 & 7th - 8th & 132 & 0.95 & 80 & 0.95 & 52 & 0.94 \\
7 th & 2008 & 7th & 89 & 0.93 & 49 & 0.96 & 40 & 0.90 \\
7 th & Pooled & 7th - 8th & 221 & 0.94 & 129 & 0.95 & 92 & 0.92 \\
\hline
\end{tabular}

NOTES: This table summarizes the lottery cohorts and match rates from SEED lottery files to SEED administrative data, District of Columbia Comprehensive Assessment System (DC CAS) data, and Maryland School Assessment (MSA) data. The sample consists of students in the SEED School of Washington, D.C., lotteries in 2007 and 2008. Panel A shows the breakdown of different types of records in the student lottery files. Panel B shows the breakdown of winners and losers in each lottery sample, as well as match rates. The match rate shown is the proportion of students for whom at least one DC CAS or MSA score in either math or reading was matched. 
Table 2: Descriptive Statistics and Covariate Balance

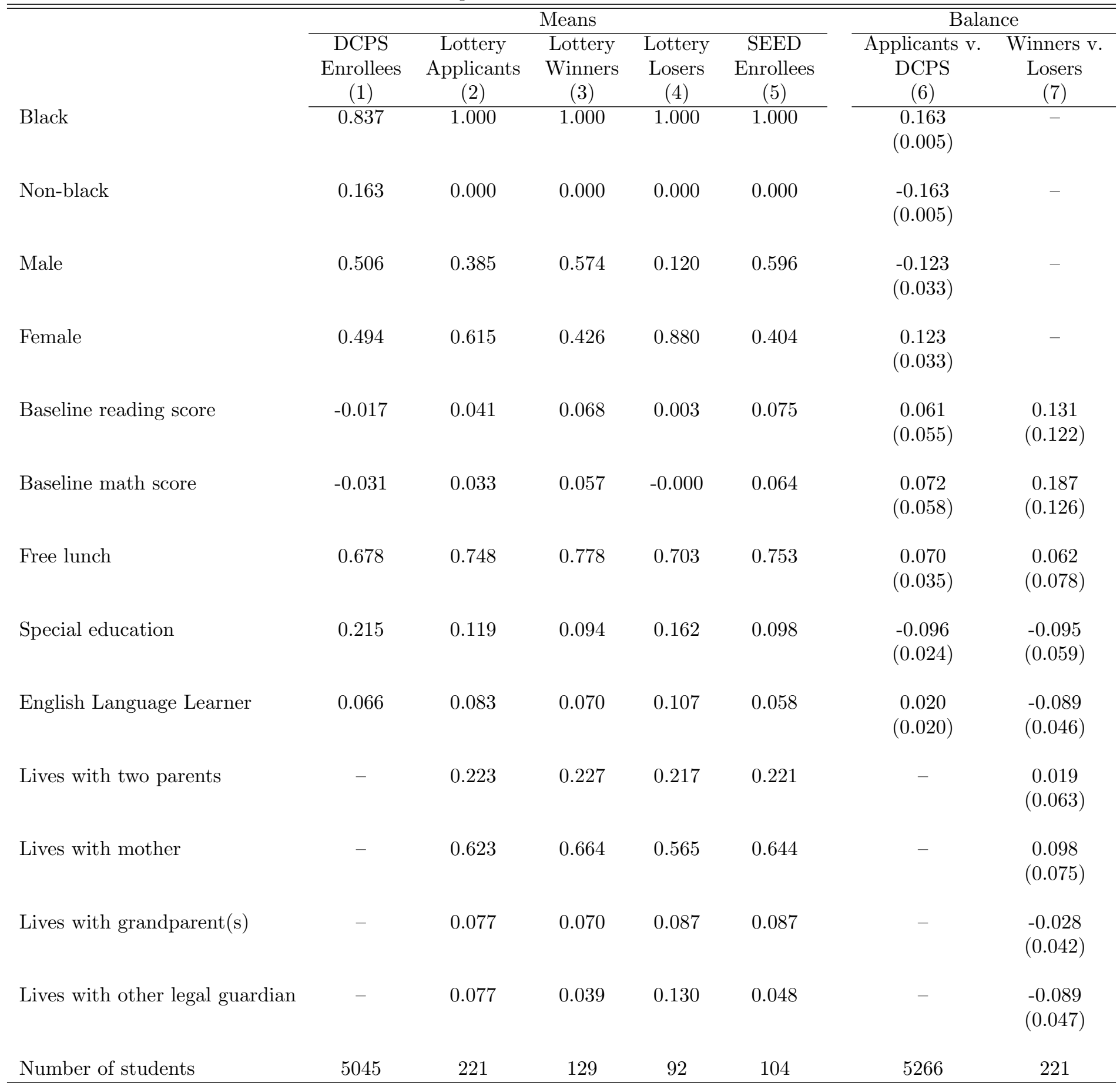

NOTES: Columns (1)-(5) report means of the variable indicated in each row. Column (1) reports means for students who were enrolled in seventh grade in District of Columbia Public Schools (DCPS) in 2007-08 and 2008-09. Column (2) reports means for all SEED lottery applicants. Column (3) reports means for SEED lottery winners and Column (4) reports means for SEED lottery losers. Column (5) reports means for lottery applicants who enrolled in SEED for at least one day. Column (6) reports coefficients from regressions of the variable indicated in each row on an indicator variable equal to one if the student was a SEED lottery applicant and zero if the student is from the DCPS seventh grade sample from Column (1). Column (7) reports coefficients from regressions of the variable indicated in each row on an indicator variable equal to one if the student won the lottery. Because SEED holds separate lotteries for male and female applicants, these regressions include an indicator variable equal to one if the student is male, and results for Column (7) are not reported for sex indicator variables. Because every applicant in the lottery sample is black, results for Column (7) are not reported for race indicator variables. The pooled regression in Column (7) combines the 2007 and 2008 cohorts and includes dummies for applicant year as well as a contemporaneous sibling dummy and the interaction of the contemporaneous sibling dummy with applicant year. The number of students in each sample is reported in the final row. Robust standard errors are reported in parentheses. 
Table 3: Lottery Results

\begin{tabular}{|c|c|c|c|c|}
\hline Outcome & Controls & $\begin{array}{c}\text { First } \\
\text { Stage } \\
(1)\end{array}$ & $\begin{array}{c}\text { Reduced } \\
\text { Form } \\
(2)\end{array}$ & $\begin{array}{c}2 \text { SLS } \\
(3)\end{array}$ \\
\hline \multirow[t]{4}{*}{ Reading } & Basic & $\begin{array}{c}0.934 \\
(0.075)\end{array}$ & $\begin{array}{c}0.236 \\
(0.100)\end{array}$ & $\begin{array}{c}0.252 \\
(0.106)\end{array}$ \\
\hline & Baseline Scores & $\begin{array}{c}0.922 \\
(0.076)\end{array}$ & $\begin{array}{c}0.168 \\
(0.081)\end{array}$ & $\begin{array}{c}0.182 \\
(0.088)\end{array}$ \\
\hline & \multirow[t]{2}{*}{$\begin{array}{c}\text { Baseline Scores } \\
\text { and Demographics }\end{array}$} & $\begin{array}{c}0.949 \\
(0.078)\end{array}$ & $\begin{array}{c}0.188 \\
(0.087)\end{array}$ & $\begin{array}{c}0.198 \\
(0.093)\end{array}$ \\
\hline & & & 303 & \\
\hline \multirow[t]{4}{*}{ Math } & Basic & $\begin{array}{c}0.933 \\
(0.075)\end{array}$ & $\begin{array}{c}0.384 \\
(0.116)\end{array}$ & $\begin{array}{c}0.412 \\
(0.122)\end{array}$ \\
\hline & Baseline Scores & $\begin{array}{c}0.921 \\
(0.076)\end{array}$ & $\begin{array}{c}0.283 \\
(0.083)\end{array}$ & $\begin{array}{c}0.307 \\
(0.090)\end{array}$ \\
\hline & \multirow[t]{2}{*}{$\begin{array}{c}\text { Baseline Scores } \\
\text { and Demographics }\end{array}$} & $\begin{array}{c}0.949 \\
(0.078)\end{array}$ & $\begin{array}{c}0.218 \\
(0.081)\end{array}$ & $\begin{array}{c}0.230 \\
(0.084)\end{array}$ \\
\hline & & & 301 & \\
\hline
\end{tabular}

NOTES: This table reports estimates of the effect of attending SEED on achievement. The sample is students who applied to the SEED School of Washington, D.C., in 2007 and 2008. Columns (1)-(3) report the first stage, reduced form, and 2SLS coefficients from instrumenting years in SEED using an indicator for having won the SEED lottery. This indicator is equal to one if the applicant was offered admission either immediately or off the waitlist. Applicants with sibling priority or who applied late and were not included in the original lottery are excluded. All regressions include an indicator variable for sex, since separate lotteries were conducted for males and females. All regressions combine the 2007 and 2008 cohorts and include dummies for grade of test and applicant year as well as a contemporaneous sibling dummy and the interaction of the contemporaneous sibling dummy with applicant year. Estimates are also reported for regressions including controls for baseline test scores in reading and math as well as demographic controls for free lunch eligibility, special education status, and English Language Learner status. Because every applicant in the lottery sample is black, race controls are not included. Robust standard errors (clustered at the student level) are reported in parentheses. Numbers of observations are reported directly below each set of estimates. 
Table 4: Lottery Results by Subsample

\begin{tabular}{|c|c|c|c|c|c|c|c|c|c|c|}
\hline Outcome & $\begin{array}{c}\text { Full } \\
\text { Sample } \\
(1)\end{array}$ & $\begin{array}{l}\text { Male } \\
(2)\end{array}$ & $\begin{array}{c}\text { Female } \\
\text { (3) }\end{array}$ & $\begin{array}{c}\text { p-value } \\
(4)\end{array}$ & $\begin{array}{c}\text { Free } \\
\text { Lunch } \\
(5)\end{array}$ & $\begin{array}{c}\text { Non- } \\
\text { Free } \\
\text { Lunch } \\
(6)\end{array}$ & $\begin{array}{c}\text { p-value } \\
(7)\end{array}$ & $\begin{array}{c}\text { Special } \\
\text { Education } \\
(8)\end{array}$ & $\begin{array}{c}\text { Non- } \\
\text { Special } \\
\text { Education } \\
(9)\end{array}$ & $\begin{array}{c}\text { p-value } \\
(10)\end{array}$ \\
\hline Reading & $\begin{array}{c}0.198 \\
(0.093) \\
303\end{array}$ & $\begin{array}{c}-0.138 \\
(0.145) \\
94\end{array}$ & $\begin{array}{c}0.382 \\
(0.155) \\
126\end{array}$ & 0.014 & $\begin{array}{c}0.254 \\
(0.123) \\
184\end{array}$ & $\begin{array}{c}0.023 \\
(0.075) \\
58\end{array}$ & 0.109 & $\begin{array}{c}0.105 \\
(0.235) \\
38\end{array}$ & $\begin{array}{c}0.224 \\
(0.100) \\
250\end{array}$ & 0.640 \\
\hline Math & $\begin{array}{c}0.230 \\
(0.084) \\
301\end{array}$ & $\begin{array}{c}0.037 \\
(0.156) \\
94\end{array}$ & $\begin{array}{c}0.265 \\
(0.142) \\
125\end{array}$ & 0.280 & $\begin{array}{c}0.196 \\
(0.104) \\
183\end{array}$ & $\begin{array}{c}0.125 \\
(0.108) \\
58\end{array}$ & 0.636 & $\begin{array}{c}0.102 \\
(0.302) \\
38\end{array}$ & $\begin{array}{c}0.288 \\
(0.090) \\
249\end{array}$ & 0.555 \\
\hline
\end{tabular}

NOTES: This table reports estimates of the effect of attending SEED on achievement for subsets of the lottery sample. Columns (1)-(3), (5)-(6), and (8)-(9) report 2SLS coefficients from instrumenting years in SEED using an indicator for having won the SEED lottery. This indicator is equal to one if the applicant was offered admission either immediately or off the waitlist. Columns (4), (7), and (10) report p-values for the F-test for the hypothesis that the coefficients in the preceding two columns are equal. Applicants with sibling priority or who applied late and were not included in the original lottery are excluded. All regressions include an indicator variable for sex, since separate lotteries were conducted for males and females. Because every single male student in the 2008 lottery was offered admission to SEED, the regressions for males and females in Columns (2) and (3) only include the 2007 cohort and include grade of test dummies and a contemporaneous sibling dummy. All other regressions combine the 2007 and 2008 cohorts and include dummies for grade of test and applicant year as well as a contemporaneous sibling dummy and the interaction of the contemporaneous sibling dummy with applicant year. All regressions include controls for baseline test scores in reading and math as well as demographic controls for race, free lunch eligibility, special education status, and English Language Learner status. Because every applicant in the lottery sample is black, race controls are not included. Robust standard errors (clustered at the student level) are reported in parentheses. Numbers of observations are reported directly below standard errors. 
Table 5: Distribution Effects

\begin{tabular}{|c|c|c|c|c|c|c|}
\hline \multirow[b]{2}{*}{ Outcome } & \multirow[b]{2}{*}{$\begin{array}{c}\text { Non-Missing } \\
\text { Baseline } \\
\text { Score } \\
(1)\end{array}$} & \multicolumn{3}{|c|}{ Effects by Baseline Score Quantile } & \multicolumn{2}{|c|}{ 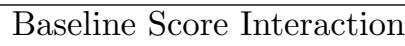 } \\
\hline & & $\begin{array}{c}\text { Below } \\
\text { Median } \\
(2)\end{array}$ & $\begin{array}{c}\text { Above } \\
\text { Median } \\
(3)\end{array}$ & $\begin{array}{c}\text { p-value } \\
(4)\end{array}$ & $\begin{array}{c}\text { Main } \\
\text { Effect } \\
(5)\end{array}$ & $\begin{array}{c}\text { Interaction } \\
\text { Term } \\
(6)\end{array}$ \\
\hline Reading & $\begin{array}{c}0.144 \\
(0.087) \\
272\end{array}$ & $\begin{array}{c}0.314 \\
(0.140) \\
139\end{array}$ & $\begin{array}{c}-0.048 \\
(0.081) \\
133\end{array}$ & 0.025 & $\begin{array}{c}0.156 \\
(0.094) \\
272\end{array}$ & $\begin{array}{c}-0.112 \\
(0.135) \\
272\end{array}$ \\
\hline Mean Score by Quantile & & -0.491 & 0.653 & & & \\
\hline Math & $\begin{array}{c}0.247 \\
(0.085) \\
270\end{array}$ & $\begin{array}{c}0.354 \\
(0.129) \\
141\end{array}$ & $\begin{array}{c}0.163 \\
(0.118) \\
129\end{array}$ & 0.274 & $\begin{array}{c}0.261 \\
(0.089) \\
270\end{array}$ & $\begin{array}{c}-0.084 \\
(0.119) \\
270\end{array}$ \\
\hline Mean Score by Quantile & & -0.532 & 0.663 & & & \\
\hline
\end{tabular}

NOTES: This table reports estimates of the effect of attending SEED on achievement for students from different parts of the baseline test score distribution. Columns (1)-(3) report 2SLS coefficients from instrumenting years in SEED using an indicator for having won the SEED lottery. This indicator is equal to one if the applicant was offered admission either immediately or off the waitlist. Column (1) reports estimates for the sample of students with non-missing baseline scores in the same subject as the outcome. Columns (2)-(3) report estimates for the groups that are below the median and above the median in terms of baseline score in the same subject as the outcome. Column (4) reports the p-value for the F-test for the hypothesis that the coefficients for the Below Median and Above Median groups are the same. Columns (5) and (6) report results from models interacting baseline test score with years in SEED. Main effects are at the mean. The interaction models are estimated by including an indicator for having won the SEED lottery interacted with baseline score as a second instrument. Applicants with sibling priority or who applied late and were not included in the original lottery are excluded. All regressions include an indicator variable for sex, since separate lotteries were conducted for males and females. All regressions combine the 2007 and 2008 cohorts and include dummies for grade of test and applicant year as well as a contemporaneous sibling dummy and the interaction of the contemporaneous sibling dummy with applicant year. All regressions include controls for baseline test scores in reading and math as well as demographic controls for free lunch eligibility, special education status, and English Language Learner status. Because every applicant in the lottery sample is black, race controls are not included. Robust standard errors (clustered at the student level) are reported in parentheses. Numbers of observations are reported directly below standard errors. Mean baseline score by quantile is also reported below each set of estimates. 
Table 6: Attrition

\begin{tabular}{|c|c|c|c|c|c|}
\hline \multirow[b]{2}{*}{ Outcome } & \multirow{2}{*}{$\begin{array}{c}\text { Share of } \\
\text { Lottery } \\
\text { Winners } \\
\text { with } \\
\text { Scores } \\
(1)\end{array}$} & \multirow{2}{*}{$\begin{array}{c}\text { Share of } \\
\text { Lottery } \\
\text { Losers } \\
\text { with } \\
\text { Scores } \\
(2)\end{array}$} & \multicolumn{3}{|c|}{ Differential Follow-up (Winner - Loser) } \\
\hline & & & $\begin{array}{c}\text { Basic } \\
(3)\end{array}$ & Baseline Scores & $\begin{array}{l}\text { Baseline Scores } \\
\text { and Demographics }\end{array}$ \\
\hline Reading & 0.861 & 0.879 & $\begin{array}{l}-0.011 \\
(0.040)\end{array}$ & $\begin{array}{l}-0.017 \\
(0.040)\end{array}$ & $\begin{array}{l}-0.031 \\
(0.040)\end{array}$ \\
\hline Math & 0.861 & 0.864 & $\begin{array}{c}0.001 \\
(0.040)\end{array}$ & $\begin{array}{l}-0.006 \\
(0.040)\end{array}$ & $\begin{array}{l}-0.024 \\
(0.040)\end{array}$ \\
\hline Number of observations & 209 & 140 & 349 & 349 & 349 \\
\hline
\end{tabular}


Table 7: Discounted Present Values of Costs and Benefits

A. SEED

\begin{tabular}{|c|c|c|c|c|}
\hline \multirow{3}{*}{$\begin{array}{l}\text { Discount } \\
\text { Rate } \\
(1)\end{array}$} & \multirow{3}{*}{$\begin{array}{c}\text { Cost } \\
(2009 \$) \\
(2)\end{array}$} & \multicolumn{3}{|c|}{$\begin{array}{l}\text { Increase in Income } \\
\text { Assuming Annual } \\
\text { Productivity } \\
\text { Growth Rate of: }\end{array}$} \\
\hline & & $0 \%$ & $1 \%$ & $2 \%$ \\
\hline & & $(3)$ & (4) & $(5)$ \\
\hline 0.01 & 42,874 & 105,867 & 111,268 & 116,886 \\
\hline 0.02 & 42,161 & 77,926 & 81,901 & 86,037 \\
\hline 0.03 & 41,468 & 58,470 & 61,452 & 64,555 \\
\hline 0.04 & 40,795 & 44,678 & 46,957 & 49,328 \\
\hline 0.05 & 40,141 & 34,729 & 36,500 & 38,343 \\
\hline 0.06 & 39,506 & 27,426 & 28,825 & 30,281 \\
\hline Internal Rate of Return: & & $4.38 \%$ & $4.59 \%$ & $4.80 \%$ \\
\hline
\end{tabular}

B. "No Excuses" Charter Schools

\begin{tabular}{|c|c|c|c|c|}
\hline \multirow{3}{*}{$\begin{array}{l}\text { Discount } \\
\text { Rate } \\
\text { (1) }\end{array}$} & \multirow{3}{*}{$\begin{array}{c}\text { Cost } \\
(2009 \$) \\
(2)\end{array}$} & \multicolumn{3}{|c|}{$\begin{array}{l}\text { Increase in Income } \\
\text { Assuming Annual } \\
\text { Productivity } \\
\text { Growth Rate of: }\end{array}$} \\
\hline & & $0 \%$ & $1 \%$ & $2 \%$ \\
\hline & & $(3)$ & $(4)$ & $(5)$ \\
\hline 0.01 & 3,566 & 85,293 & 89,644 & 94,171 \\
\hline 0.02 & 3,521 & 62,782 & 65,985 & 69,317 \\
\hline 0.03 & 3,476 & 47,107 & 49,510 & 52,010 \\
\hline 0.04 & 3,433 & 35,995 & 37,832 & 39,742 \\
\hline 0.05 & 3,390 & 27,979 & 29,407 & 30,892 \\
\hline 0.06 & 3,349 & 22,096 & 23,223 & 24,396 \\
\hline Internal Rate of Return: & & $18.07 \%$ & $18.50 \%$ & $18.93 \%$ \\
\hline
\end{tabular}

NOTES: Figures assume that a one standard deviation increase in either reading or mathematics scores is associated with an 8 percent increase in earnings, and that attending SEED in grades 6-8 raises reading scores by .198 standard deviations per year and raises math scores by .230 standard deviations per year. Real wages are assumed to grow at the same rate as productivity. Costs and benefits are based on the assumption that students who are admitted to SEED actually attend SEED for, on average, approximately 2.3 out of the 3 middle school years they could possibly attend. It is assumed that attending a "No Excuses" charter school in grades 6-8 raises reading scores by .149 standard deviations per year and raises math scores by .405 standard deviations per year. These estimates are taken from a study of "No Excuses" charter schools by Abdulkadiroglu et al. (2009). Costs and benefits are based on the assumption that students who are admitted to a "No Excuses" charter school actually attend a "No Excuses" charter for, on average, approximately 1.4 out of the 3 middle school years they could possibly attend. 
Appendix Figure 1. SEED Treatment and Control Households

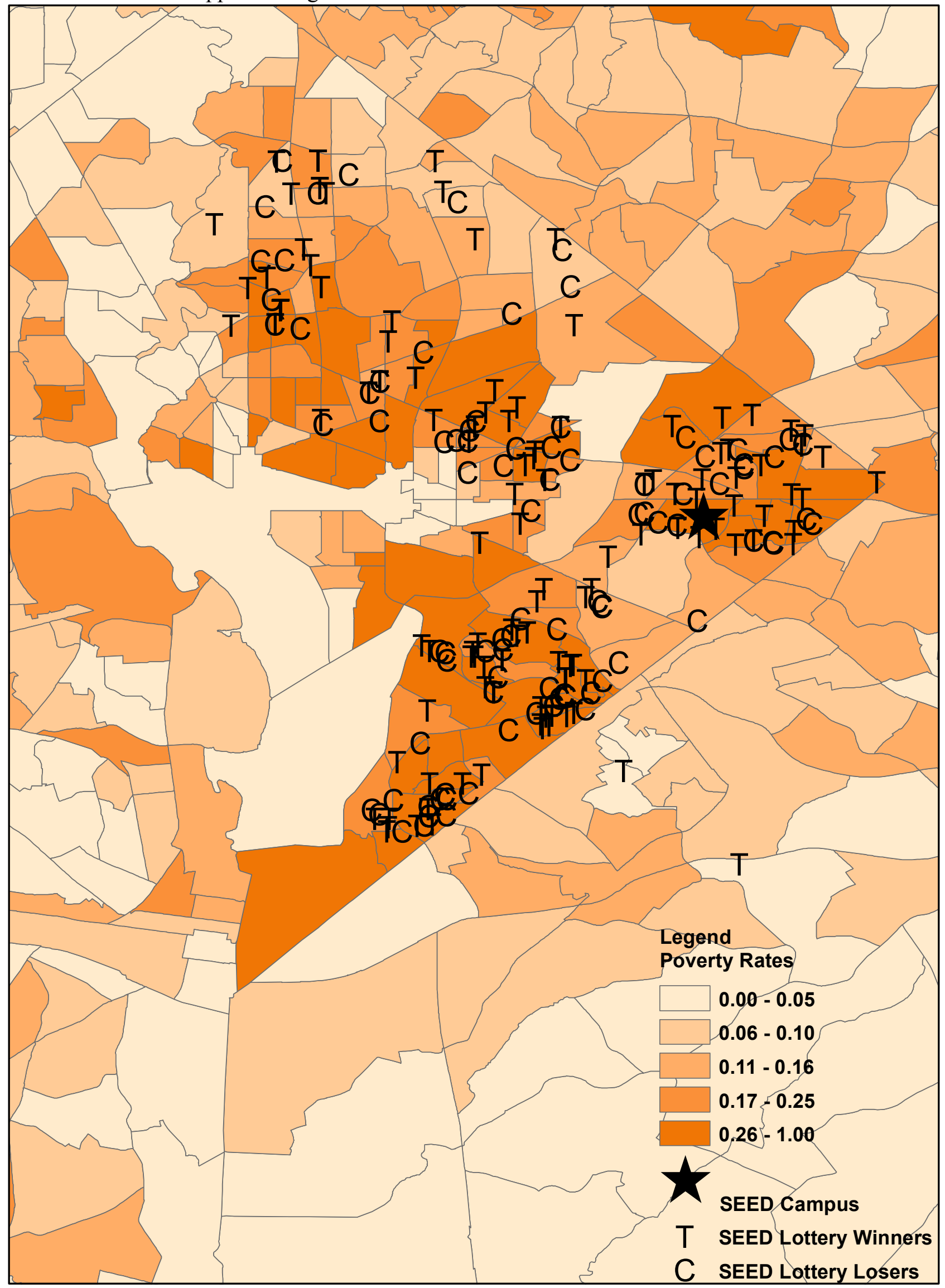

2.5 